
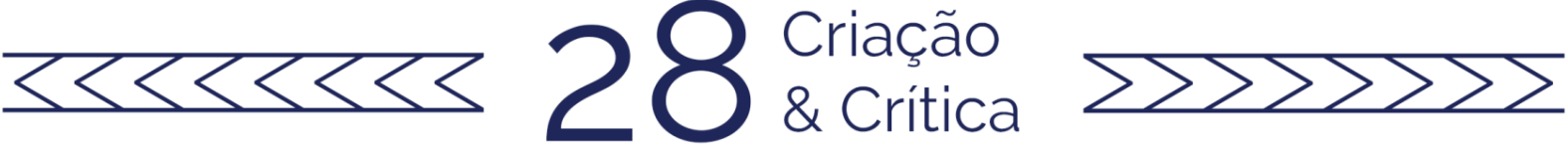

\title{
"DÁ PRA FALAR BELO ASSIM?" : ANA CRISTINA CESAR, EMBATES E FIGURAÇÕES DO CORPO NA ESCRITA
}

Fernanda Morse ${ }^{1}$

Resumo: O presente artigo visa investigar os usos do corpo na obra de Ana Cristina Cesar através da análise de três poemas presentes na recolha da Pasta Rosa (2008): "25 de maio de 1976"; "era noite e uma luva de angústia..." e "idispiando". Para tanto, lançamos mão tanto de textos que nos situam nas discussões lançadas pelos próprios poemas, quanto daqueles que tangenciam o período de sua produção. Buscamos entender certo percurso de inserção do corpo nas manifestações artísticas brasileiras com o apoio do trabalho Corpos Pagãos (2015) de Mário Cámara, assim como o contexto literário em que a produção de Ana C. se insere, partindo de textos de Heloisa Buarque de Hollanda, Glauco Mattoso e Viviana Bosi. Por fim, compreendemos que esses poemas deixados "à sombra" podem iluminar a leitura daqueles publicados em vida pela autora, em uma relação complementar e esclarecedora para aqueles que se aventuram entre as elipses de Ana C.

Palavras-Chave: Ana Cristina Cesar; corpo; provocação; projeto político-literário; escrita feminina

\section{“IS IT POSSIBLE TO SPEAK THAT BEAUTIFULLY?”: ANA CRISTINA CESAR, STRUGGLES AND FIGURATIONS OF THE BODY IN THE WRITING}

ABSTRACT: This article aims to investigate the uses of the body in the work of Ana Cristina Cesar through the analysis of three poems present in the collection of Pasta Rosa (2008): "25 de maio de 1976"; "era noite e uma luva de angústia..." and "idispiando". For this, we use both texts that situate us in the discussions launched by the poems themselves, as well as those that touch the period of their production. We seek to follow a certain path of insertion of the body in the Brazilian artistic manifestations with the support of the work Corpos Pagãos (2015) by Mário Cámara, as well as the literary context in which the production of Ana $\mathrm{C}$. is inserted, based on texts by Heloisa Buarque de Hollanda, Glauco Mattoso and Viviana Bosi. In conclusion, we understand that these poems left "in the shade" can illuminate the reading of those published in life by the author, in a complementary and enlightening relationship for those who venture among the ellipses of Ana C.

KEYWORDS: Ana Cristina Cesar; body; provocation; political-literary project; feminine writing

।

Em 2008, veio à tona, editado pelo IMS e organizado por Viviana Bosi, o livro que reúne os poemas "prontos, mas rejeitados" de Ana Cristina Cesar, intitulado "Antigos e

\footnotetext{
${ }^{1}$ Mestranda no Departamento de Teoria Literária e Literatura Comparada da FFLCH-USP. Pesquisou por dois anos e meio a obra de Ana Cristina Cesar com apoio da FAPESP, contando com um estágio de pesquisa no Institut d'Études Ibériques et Latino-américaines da Université Paris-Sorbonne. Como trabalho final da graduação, traduziu uma antologia de poemas da norte-americana Diane di Prima.
} 

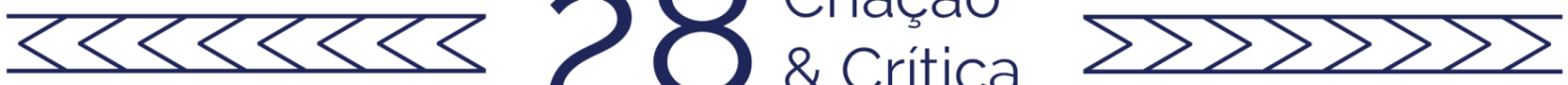

soltos - poemas e prosas da pasta rosa." Estariam ali reunidos, entre outros, textos que Ana C. concluiu mas considerou impublicáveis dentro do material que pôde divulgar em vida. Não por acaso, é ali que encontramos trabalhos com maior teor escatológico e "escrachado", explorando aspectos do corpo que de costume são apagados, escondidos e, quando abordados, delegados ao pudor das metáforas ou das sugestões. Se em "Cenas de Abril" (1979), seu primeiro livro, a autora trata da plural "coceira no hímen", no poema "arpejos", na "Pasta Rosa" há lugar para peidos, cocôs e caralhos. Também em "Inéditos e Dispersos" (1985), coletânea anterior a esta aqui mencionada, que inclui igualmente poemas não eleitos para publicação pela autora, nos deparamos com uma investigação dos baixos corporais em textos como "Conto de Natal" (onde uma mãe perversa chama os filhos para verem o "troço" que saiu da sua barriga boiar na privada), ou no poema que se inicia com "As horas fundamentais já nos visitaram", onde o sujeito lírico escreve enquanto urina no banheiro do bar, com as calças baixas, olhando os sapatos brancos.

Toda essa abordagem parece fazer parte, entre outras coisas, de uma oposição consciente da autora a uma ideia inefável de poesia de mulher que era sustentada pelo cânone de sua época, como explicita no texto "Literatura e mulher, essa palavra de luxo" (1979), presente no volume Crítica e Tradução (1999), em que a Ana C. critica o universo asséptico que permeia parte da obra de Cecília Meireles e Henriqueta Lisboa e como ele se enquadraria, então, no senso comum do que é poesia e, sobretudo, da poesia escrita por mulheres. Na esteira de uma proposta estética dessacralizadora protagonista na agenda da Poesia Marginal, dos seus contemporâneos, Ana Cristina Cesar encara a inserção desses elementos corporais "baixos" na escrita também como um projeto político, assim como lemos em certa altura da recolha da "Pasta Rosa": "E o projeto político-literário: despoetizar a escrita feminina. Suprimir o mito do sexto sentido, da doce e inefável poesia feminina. A falsa grávida com gases." (CESAR, 2013, p. 319) Voltaremos a esse poema em breve, mas, falando em gases, comecemos com a análise do poema intitulado "25 de maio de 1976":

\section{5 de maio de 1976}

Falta em Machado a menção a peidos. Peido incessantemente. Peidos presos oprimem. Dia cheio. Tempestade violenta de manhã. Helô também tem medo, me disse à parte. Deu frio misterioso na barriga quando estudava, alegoria, símbolo. Já posso estudar se ajudam. Mas se chove muito imagino catástrofes. Penso na literatura que vivemos estudando. Será possível escrever com toda Consciência? Símbolo, alegoria, ou o que for? Helô também tem medo de avião? Queria casar. Casamento é que é bom. Derramo café na calça branca, lavo longamente pra me distrair. Histórias de desquites. Gases, medos. Me esparramei como garotinha no sofá, barriga pra baixo e pernas pra cima. (CESAR, 2013, p. 375)

Notamos aqui, antes de tudo, um aspecto comum à obra de Ana C.: a apropriação dos moldes de uma escrita de diário, a julgar pelo título do poema que é uma data, 

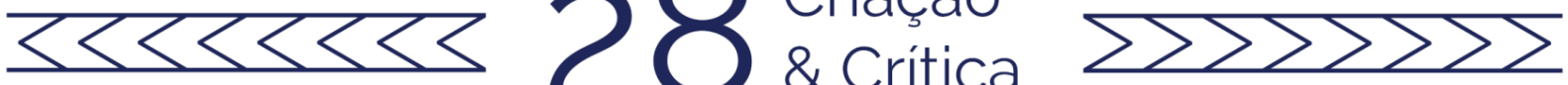

inscrevendo o texto em um suposto registro da intimidade. O que lemos, no entanto, não é simplesmente a confissão de uma inquietação íntima: entre anotações cotidianas como "dia cheio", encontram-se questionamentos acerca da escrita e uma espécie de crítica a um grande ícone da literatura brasileira, assim como a inserção do debate teórico que permeia a oposição entre o símbolo e a alegoria. Paira pelo poema o desconforto, um jogo de oposições que se encontram entre o programa e o acidente ${ }^{2}$. Em meio a tanta assimetria e mistura de registros, parece se reivindicar uma descompostura que, inferimos pelo julgamento do poema, faria falta na obra do consagrado Machado de Assis, ou mesmo na considerada "alta literatura".

Sabemos que Ana Cristina Cesar, ao escrever os seus poemas, seus artigos ou suas cartas, mantém uma coesão temática, reflexiva e, por vezes, formal entre os trabalhos - o que nos permite relacionar a menção aos estudos do símbolo e da alegoria ao processo de escrita de um artigo publicado pela autora no mês seguinte à data-título do poema em questão, no jornal Opinião, intitulado "Nove bocas da nova musa". Nesse texto crítico, Ana C. comenta sobre as características da produção poética de seus contemporâneos e, a partir do texto de José Guilherme Merquior sobre o mesmo tema e de sua referência benjaminiana, traz a oposição estilo simbólico/estilo alegórico para dentro da análise e discussão (além da oposição estilo puro ou elevado/ estilo impuro ou mesclado sinalizada como de Erich Auerbach ${ }^{3}$ ).

Cabe aqui, portanto, a nossa tentativa de situar a problemática que envolve o par símbolo/alegoria naquela época. Podemos encarar esse debate como uma extensão daquele levantado quando se buscou refletir sobre a estética do movimento tropicalista, considerando, por sua vez, que tal oposição ganha destaque após a recepção no Brasil das considerações de Walter Benjamin em "A origem do drama barroco alemão" (1928). Benjamin, em seu trabalho, toma partido da alegoria como um recurso legítimo de produção de significado, uma vez que, diferentemente de abordagens como as do classicismo, que consistiam em "denunciar a alegoria vendo nela um modo de ilustração, e não uma forma de expressão", o seu livro se guia pelo desejo de "demonstrar, pelo contrário, que a alegoria não é frívola técnica de ilustração por imagens, mas expressão" (BENJAMIN, 1984, p. 184). Sua oposição ao estilo simbólico se daria, entre outros fatores, pelo viés fragmentário, já que o modo de expressão da construção simbólica se

\footnotetext{
2 Identificamos as seguintes oposições entre programa e acidente/ segurança e risco: Machado x peidos; Dia cheio (entendido como cheio de afazeres, compromissos) $x$ tempestade/medo; estudar símbolo, alegoria $x$ catástrofes; escrever com toda a consciência $x$ menção a peidos; casar $x$ derramar café na calça branca/ desquites

3 "Para Merquior a nossa poesia mais recente e mais radical caracteriza-se primeiramente pelo 'estilo mesclado', ou seja, retoma a lição moderna, inaugurada por Baudelaire, que abole a distinção rígida de estilos, misturando a visão poética problematizante com temas e expressões vulgares, criando assim uma tensão com esse convívio do sério e do coloquial." (CESAR, 1999, p. 163) Tensão que, por sua vez, está presente na própria escrita da autora e, mais especificamente, no poema que estabelece uma relação direta com esse texto e que analisamos agora. A propósito dessa relação estabelecida, ela se faz mais evidente quando olhamos o manuscrito de " 25 de maio..." e nos deparamos com o nome de Auerbach riscado antes dos termos "símbolo, alegoria".
} 

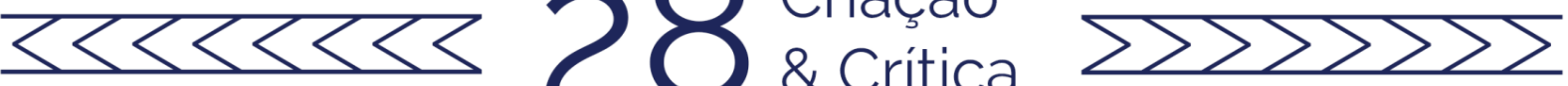

preocuparia em criar uma indissociabilidade, uma totalidade entre forma e conteúdo. A esse respeito, Benjamin diz:

E ainda hoje não é óbvio que ao representar a primazia das coisas sobre as pessoas, do fragmentário sobre o total, a alegoria seja o contrário polar do símbolo, mas por isso mesmo sua igual. A personificação alegórica obscureceu o fato de que sua tarefa não era a de personificar o mundo das coisas, e sim a de dar a essas coisas uma forma mais imponente, caracterizando-as como pessoas. (BENJAMIN, 1984, p. 209)

Trazendo tais considerações sobre a alegoria para o debate no contexto brasileiro, Roberto Schwarz em "Cultura e Política, 1964 - 1 969" (1978) identifica procedimentos alegóricos no tropicalismo já anunciando o empréstimo desse vocabulário como advindo do texto de Benjamin, ainda que adotando uma postura menos receptiva acerca de tal prática. Schwarz nota como um dos traços mais característicos do movimento tropicalista a sobreposição de imagens e princípios antagônicos, que seriam os elementos arcaicos da cultura brasileira somados a materiais e temáticas "ultra-modernas" apropriadas não só de correntes artísticas, mas de elementos culturais variados dos países dito "avançados", cujo intuito seria forjar uma alegoria do Brasil, esse bicho ambivalente em estado crítico. Tal mistura, segundo Schwarz, geraria um choque de referências que por vezes podia ser contestatório e provocador, mas que também podia agregar um teor apologético, no ponto em que o movimento se aproximaria simplesmente dos procedimentos e dos intuitos da cultura pop, e, por sua vez, do seu viés mercadológico ${ }^{4}$.

Uma década depois, Heloisa Buarque de Hollanda faz um comentário à crítica de Schwarz em certa altura do seu livro Impressões de viagem: CPC, vanguarda e desbunde, 1960-1970 (1980), vendo sua postura próxima àquela do jovem Lukács realista, cuja crítica à alegoria estaria ligada à exigência de uma "perspectiva finalista para a obra de arte" (HOLLANDA, 1980, p. 69). Schwarz criticaria, então, no procedimento tropicalista, "a sua incapacidade de sugerir que as aberrações e os contrastes do capitalismo brasileiro são historicamente determinados e superáveis. Faltaria ao Tropicalismo a indicação dessa superação." (HOLLANDA, op. cit.). Hollanda segue comentando, por sua vez, que justamente a intenção dos artistas desse movimento é opor-se a tal posicionamento e demanda da esquerda, havendo ali uma descrença

em relação à ideia da tomada de poder, a revolução marxista-leninista que já estava dando provas, na prática, de um autoritarismo e de uma burocratização nada atraentes. (...) O Tropicalismo começa a sugerir uma

\footnotetext{
4 "Arriscando um pouco, talvez se possa dizer que o efeito básico do tropicalismo está justamente na submissão de anacronismos desse tipo, grotescos à primeira vista, inevitáveis à segunda, à luz branca do ultra-moderno, transformando-se o resultado em alegoria do Brasil. A reserva de imagens e emoções próprias ao país patriarcal, rural e urbano, é exposta à forma ou técnica mais avançada ou na moda mundial - música eletrônica, montagem einsensteiniana, cores e montagem do pop, prosa de Finnegans Wake, cena ao mesmo tempo crua e alegórica, atacando fisicamente a plateia." (SCHWARZ, 1978, p. 74)
} 

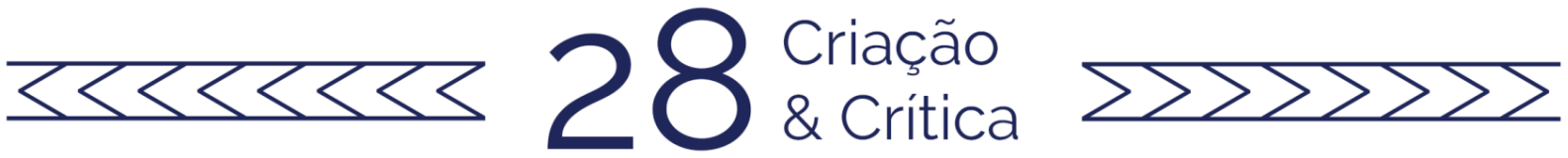

preocupação com o aqui e agora, começa a pensar a necessidade de revolucionar o corpo e o comportamento. (HOLLANDA, 1980, p. 70)

Por essas e outras conseguimos traçar, então, algumas linhas de continuidade entre os procedimentos dos quais se lançava mão a produção artística no auge do tropicalismo, nos anos 60, e aqueles de que se utilizava a geração que por vezes é chamada Marginal no âmbito da poesia, que surge nos anos 70 - valendo a observação de Ana Cristina, ainda via Merquior: "A dicção mesclada, o estilo alegórico e o ânimo de denúncia definiriam não a nova poesia em sua totalidade mas, segundo Merquior, o seu caminho mais moderno e radical"5. Podemos notar, contudo, que o ponto do aqui e agora, assim como o campo da revolução do corpo e do comportamento, se estendeu quase por completo às inquietações da geração de escritores e artistas contemporâneos a Ana C., como também aponta Viviana Bosi em seu texto "Sobrevoo entre as artes (à volta das décadas de 1960 e 1970)" (2018):

A relação entre eles decorria do projeto um tanto nebuloso de 'mudar a vida', 'politizar o cotidiano'. (...) Se estas produções culturais convulsas atraídas pela relativização da perenidade da arte, tendem à extinção de uma orientação para a permanência, causando a impressão de uma 'experiência enfraquecida de futuro' (na expressão de Jameson), nem por isso abandonaram a aspiração de alterar o presente: 'mudar a forma de mudar' poderia ser um emblema característico da época. (BOSI, 2018, p. 52 e pp. 54-55)

Uma diferença, contudo, salta entre essas gerações na esfera da distribuição e do vínculo com o público. A Geração Marginal, tantas vezes também reconhecida como Geração Mimeógrafo, já tinha um outro fôlego em relação aos intuitos de se relacionar com a "massa" e com meios de grande difusão. Preservando uma atuação limítrofe, os autores faziam seus próprios livros em edições artesanais e de baixa tiragem para vender no corpo a corpo, em contato direto com os seus leitores, sem uma pretensão imediata de mobilizar o grande público ${ }^{6}$, como ainda diz Viviana Bosi no mesmo texto: "Predominou,

\footnotetext{
${ }^{5}$ Ou seja, não seria toda a poesia marginal que teria uma construção formal tão consciente e trabalhada, mas sim o segmento dessa geração que mais "ousava", sendo Ana C. um dos melhores exemplos para tal consideração.

6 Acerca desse tipo de atuação dos chamados poetas marginais, podemos lembrar de Ana Cristina caracterizando a poesia marginal como "anti-cabralina por excelência", uma vez que apostaria, entre outras coisas, no contato direto, na personalização da escrita e do vínculo do público com o artista/escritor, como meios de alcance e contato mais eficazes. A diferença entre tais posturas que visam o mesmo objetivo (a comunicação com o leitor) é comentada em artigo assinado por Tatiane Marchi e Paulo Franchetti, Ana Cristina Cesar e a poesia marginal (2009):
}

Como também observa Franchetti (op. cit.), os poetas marginais assumiram uma posição anti-cabralina, pois viam na exploração da técnica e no rigor formal, fatores que prejudicariam a comunicação imediata com o público leitor. No entanto, é curioso que o argumento contrário tenha sido utilizado por João Cabral como forma de restabelecer o contato entre a poesia e o público. No ensaio "Da função moderna da poesia" (apresentado no Congresso de Poesia de São Paulo, em 1954), o poeta pernambucano defende que as inovações formais não devem 

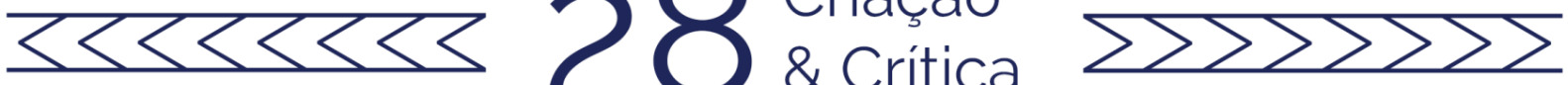

tanto nas artes plásticas quanto na poesia, a língua do pequeno grupo dissidente."(BOSI, 2018, p. 52)

Voltando ao poema e ao ponto em que nos reservamos à discussão do símbolo e da alegoria, se fosse para pensar sobre o seu próprio procedimento em relação a uma construção alegórica ou simbólica, podemos ver como, na esteira de seu tempo, a poeta faz escolhas que também se correspondem com uma fragmentação própria da alegoria, em que, recortando e se apropriando de ícones da literatura (Machado de Assis), de conceitos do universo da teoria literária e do pensamento (símbolo, alegoria) e de aspectos do corpo (peidos e outros: barriga, pernas etc.) ela compõe a paisagem do seu texto. A ideia do recorte se faz presente porque não necessariamente essas referências e aspectos vão ser explicados, desenvolvidos ou transfigurados para virar matéria poética?. Assim como vemos em diversos poemas de Ana Cristina Cesar (como "Atrás dos olhos das meninas sérias", "Carta de paris", entre outros), a menção, a breve passagem pelos universos ali nomeados é o suficiente para compor o seu jogo de forças. É esse procedimento que permite, tantas vezes, a mistura de registros e a aproximação de mundos distintos, como acontece aqui: quando se é pronunciada a falta de menção a peidos na escrita de Machado, a autora está incorporando-os à sua própria escrita e se valendo dos aspectos que o termo agrega.

Mas o que permitiria, abriria a guarda para essa investigação? Em "Nove bocas..." Ana C. comenta: "Esta literatura sabe que não está simbolizando alguma inefável verdade sobre o mundo, que não está abarcando um símbolo inexprimível; é antes uma poesia que não se dá ares, que desconfia dos plenos poderes de sua palavra." E não seria essa análise pertinente também para pensarmos a sua prática poética? Se "o poeta faz da consciência do distanciamento o seu tema e o seu tom", segundo ela, vemos em "25 de maio..." uma reafirmação disso. Diversos elementos do poema estão sendo colocado à prova: a tradição literária, os limites do corpo, os limites da escritura ("é possível escrever com toda a Consciência?"), dos conceitos, dos costumes ("queria casar"). Toda essa complexidade e mistura de registros desperta o distanciamento que passa de tema a tom, mediando a relação com o leitor.

"Falta em Machado a menção a peidos. Peido incessantemente. Peidos presos oprimem." Além de contundente pela repetição da oclusiva "p", essa sequência adota uma ironia e uma comicidade que podemos até identificar aos procedimentos do próprio Machado. A autora, portanto, não despreza aquilo que a produção do escritor evoca, o que lhe interessa é sobretudo explorar um apelo provocativo. Marcos Siscar em seu texto

desprezar a necessidade de comunicação: "o poeta moderno, que vive no individualismo mais exacerbado, sacrifica ao bem da expressão a intenção de comunicar." Assim, percebemos que para atingir um objetivo poético semelhante tornar a poesia comunicativa -, João Cabral e os poetas marginais utilizaram estratégias diferentes. (MARCHI; FRANCHETTI, 2009, p. 389)

${ }^{7}$ Schwarz, em certa altura do seu texto aqui já comentado, diz: “(...) os elementos de uma alegoria não são transfigurados artisticamente: persistem na sua materialidade documental, são como que escolhos da história real, que é a sua profundidade" (SCHWARZ, 1978, p. 78) 

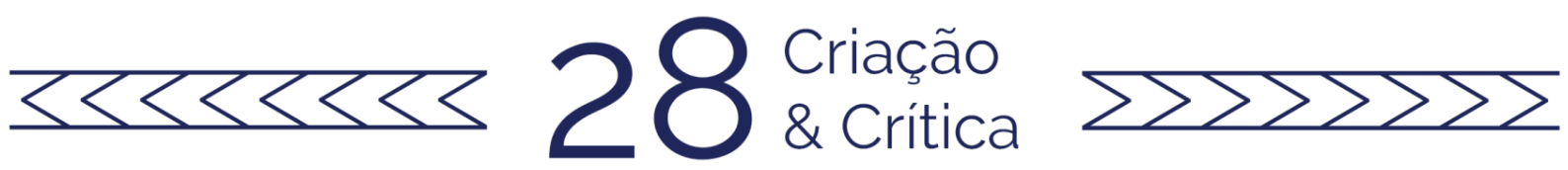

"Ana C. aos pés da letra", comenta sobre a dimensão provocativa de sua escrita principalmente quando forja aspectos da intimidade que se desdobram em diversos procedimentos, entre eles esse atrito com a tradição e a investigação de um erotismo ambíguo, do mostra não mostra, que chega a aparecer também no nosso poema (“(...) me esparramo como garotinha no sofá, barriga para baixo e pernas para cima”). A provocação abarca então duas dimensões principais: a da sedução e a da irritação, estabelecendo, como diz Siscar, uma "relação nervosa com o leitor" e um posicionamento quanto a uma "tradição poética na qual a intimidade ou o exibicionismo da intimidade são entendidos não apenas como um paradigma romântico, místico ou espontâneo de poesia, mas igualmente como um modo negativamente marcado da escrita, um modo 'feminino'." (SISCAR, 2016, pp. 112-113)

II

Isto posto, nos cabe realizar algumas observações gerais sobre a inserção do corpo e dos seus aspectos mais "ordinários" no percurso brasileiro das artes no século XX. Como podemos acompanhar no livro Corpos Pagãos (2015), de Mario Cámara, após a recuperação do modernismo brasileiro e das vanguardas europeias realizada pelos concretistas em um viés formalista, tecnicista e muitas vezes rígido, vemos movimentos subsequentes, como o Neoconcretismo, o Tropicalismo e aquelas manifestações artísticas situadas na contracultura dos anos 70, assumirem tais referências reivindicando as dinâmicas do prazer, da interação, da troca, próprias à situação do corpo na arte, seja escrita, seja plástica ${ }^{8}$. A geração de Ana Cristina, como já comentamos, está inserida nesses usos do corpo, sendo a sua obra um dos lugares onde tal prática mais salta. Mario Cámara diz:

À pergunta de Schwarz, "O vanguardista está na ponta de qual corrida?" (1992), devemos acrescentar ao menos outras duas (...): de que modo foi possível atualizar a ideologia das vanguardas? Que efeitos teria essa atualização sobre as próprias vanguardas? O corpo foi uma das respostas

\footnotetext{
${ }^{8}$ A propósito dessa rigidez formalista atribuída aos concretos, cabe recuperar uma anotação de Ana Cristina Cesar que se encontra na última página do caderno "Meios de Transporte", presente no arquivo da autora localizado no IMS. Nela, Ana C. situa a sua fala e os seus pares "sob o signo da paixão", esse afeto tão intimamente ligado à mobilização imediata dos corpos: "(...) veja-se os meus livros = entre a prosa e a poesia, entre o discursivo e o sobressalto. Redescubro João Cabral com medo. Dessa precisão. Da renúncia da sedução. Daí se segue direto para concretos, que não lembrarei agora, pra no seu fulminante localizar-se. Que fala localizada! A posição marcada. A poesia que sobressai, lúcida, pedra. A poesia que desliza, embala, plaina, seduz. O partido.
}

Me vejo muda entre partidos

a minha fala, então?

os meus pares, então?

Sob o signo da paixão." 

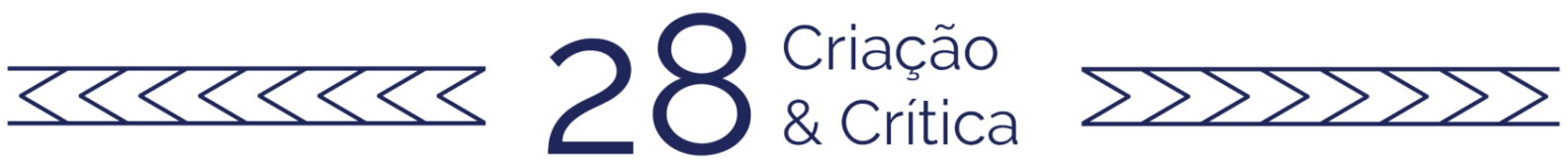

para ambas as interrogações. Se apropriar da vontade inventiva da poesia concreta, por exemplo, significava, entre outras coisas, confrontar um provincianismo opressivo que desde o final da década de 1960 não deixava de aprofundar-se; por outro lado, produzir um corpo, com seus humores, seus fluidos e seus movimentos, contribuía para desfazer os riscos de um excesso de formalismo. (CÁMARA, 2014, pp. 110-111)

Visando alongar essa discussão, traremos mais dois poemas: o "idispiando" e a versão da pasta rosa do poema que começa com "era noite e uma luva de angústia...". Uma versão reduzida integra "Cenas de Abril" (1981), com o título de "19 de abril":

Era noite e uma luva de angústia me afagava o pescoço. Composições escolares rodopiavam, todas as que eu lera e escrevera e ainda uma multidão herdada de mamãe. Era noite e uma luva de angústia... Era inverno e a mulher sozinha... Escureciam as esquinas e o vento uivando... Saí com júbilo escolar nas pernas, frases bem compostas de pornografia pura, meninas de saiote que zumbiam nas escadas íngremes. Galguei a ladeira com caretas, antecipando o frio e os sons eróticos povoando a sala esfumaçada.

- Somente uma transformação radical da infraestrutura econômica produzirá novas relações entre os homens, e consequentemente entre homens e mulheres!

- Não senhor! A revolução não acontecerá apenas num dia remoto, mas é um processo a se desenvolver a cada dia cada ato da vida cotidiana! Interferência do rapazinho inteligente: Mas como essa consciência nova ultrapassa a experiência individual para virar projeto social? Como traduzir a consciência da necessidade de relações interpessoais novas em uma ação organizada de mudança social radical?

E o projeto político-literário: Despoetizar a escrita feminina. Suprimir o mito do sexto sentido, da doce e inefável poesia feminina. A falsa grávida com gases.

- Estrutura histérica! grita a fada madrinha. Assinado embaixo:

Nós do outro sexo, do sexto sexo. (CESAR, 2013, p. 319)

O poema pode ser dividido em três partes: o primeiro parágrafo, que é o mesmo que figura sozinho em Cenas de abril, segue, a propósito, uma temática que se apresenta por todo esse livro, jogando com o imaginário do feminino, do mistério pelas reticências, do erotismo incutido em espaços de disciplina e repressão; os dois parágrafos de falas sinalizadas com o travessão, que aparecem como discursos sobrepostos de terceiros atravessados por uma voz exterior e avaliativa ("Interferência do rapazinho inteligente"); e os dois últimos parágrafos, que mais se aproximam de algo que entenderíamos como uma intervenção do "sujeito lírico", da "voz do poema", que se assemelha àquela voz que atravessa a fala anterior e que se apresenta de modo propositivo diante dos discursos até ali recortados, forjados, ironizados (com a soma do grito da "fada madrinha").

A primeira parte, então, parece se apropriar de uma voz de tom solene e reticente, com ares românticos, espectrais, que sugere um mistério ao redor da situação 

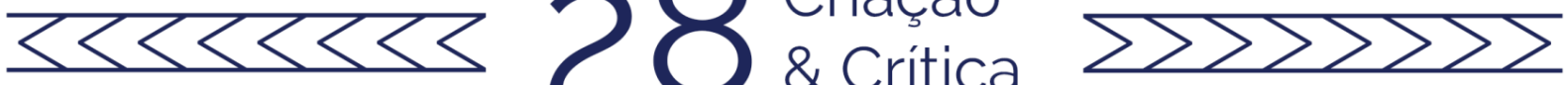

apresentada. Seria o fantasma das composições escolares, aquelas cartilhas de exercícios de escrita que traziam modelos de poemas aprumados e limpinhos para as crianças aprenderem a escrever? Acompanhamos, então, um processo de "declínio" na apropriação desse tom de cartilha, que começa solene ("Era inverno e a mulher sozinha... Escureciam as esquinas e o vento uivando...") e é tensionado, rebaixado pelas sugestões eróticas, as meninas de saia pelas escadas, a escrita pornográfica e o deboche das caretas.

$\mathrm{Na}$ segunda parte, somos incluídos em um debate comum à época de escrita do poema, os anos 70 em plena ditadura militar: de onde pode germinar uma mudança efetiva das relações e dos costumes, ou mais ainda, uma revolução? Nela está em jogo também a referência ao embate que existia entre uma produção artística mais diretamente engajada em termos políticos, como foi predominante a partir de meados dos anos 50 até o início dos anos $60^{\circ}$, e a produção ligada ao Tropicalismo e suas adjacências/consequências, como já comentamos brevemente acima. Identificamos ao menos três vozes nesse diálogo: a que fala no primeiro travessão, a que começa falando no segundo e é interpelada pelo "rapazinho inteligente" (que parece ser o mesmo do primeiro travessão) e, além delas, a voz que anuncia a "interferência" como uma espécie de "voz do narrador" até então desconhecida no texto.

A terceira parte se inicia com uma proposição, é seguida do grito de uma voz externa - em resposta, em acusação? E termina com a assinatura de um "nós", um "nós do sexto sexo". A princípio, vemos essa última parte como o momento em que se modula a disparidade entre a primeira e a segunda, pois parece assumir para cada uma delas um papel. Em relação à primeira, escancara o procedimento - entendemos que o tom até certo ponto romântico nela assumido é um modo de apropriação, de infiltração, fazendo parte então desse gesto de "despoetização" da escrita feminina; e, em relação à segunda, situa a sua frente de ataque: o projeto é político-literário, o começo da intervenção em relação ao problema colocado pelos "debatedores" se dá pela literatura.

Deseja-se "suprimir o mito do sexto sentido" da mulher, desmistificar a sua sensibilidade: recebemos então a imagem da falsa grávida com gases, que, por sua vez, se reitera em outros poemas da Pasta rosa, sendo o parto, no poema " 13 de setembro de 1977", na verdade o momento em que se defeca. A fada madrinha também aparece em "13 de setembro..." falando a mesma coisa: "estrutura histérica!" Trata-se de uma espécie de "acusação" desse personagem que surge no poema para, em vez de dar sorte (como é convencionado o seu papel nos contos de fadas), responder ao texto que lhe dá a voz por meio de um diagnóstico polêmico: proclamar a histeria de uma mulher convencionalmente significa reprimi-la. Ao mesmo tempo, é como se o poema desejasse pegar pra si uma certa potência que seria inerente a essa "estrutura histérica", fragmentária, aparentemente desorientada e cheia de ecos, que não busca se remeter a uma totalidade mas sim à ideia de montagem (traços comuns à construção alegórica aqui comentada). Há uma urgência

\footnotetext{
9 "Desde meados dos anos 1950, mas principalmente no início da década de 1960, deflagra-se (...) a cultura engajada - volta ao solo no que ele conservava de mais 'autêntico' juntamente com um propósito politizador." (BOSI, 2018, p. 31)
} 

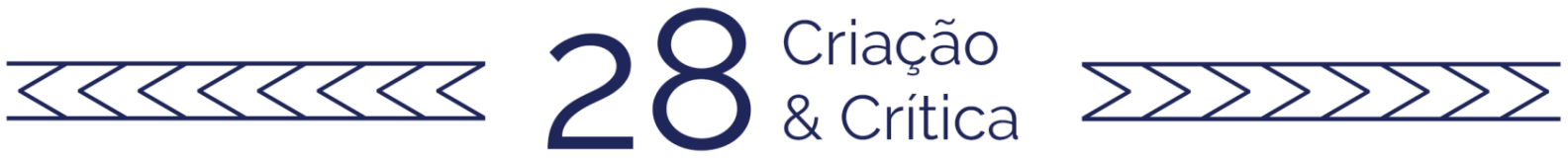

de falar através do "burburinho" (termo usado por Flora Süssekind em seu Até a segunda ordem não me risque nada, 1995) e, no meio dele, descobrir as consonâncias e dissonâncias para se poder criar um nós como se cria o "sexto sexo". Por fim, remetendo ao comentário de Cámara sobre o corpo como resposta, vemos que neste poema o corpo é abordado sobretudo pela via do estereótipo feminino, seja pela ironizarão de um suposto erotismo no primeiro parágrafo, seja pela intervenção final: deseja-se afrontar um clichê de corpo e escrita domesticados.

A fim de dar seguimento à discussão, passemos ao próximo poema:

\section{idispiando}

O casal dança coladinho às vezes me pisa o pé

falo coisinhas eles nem ouvem me deito no chão

me estão pisando a bunda abertamente

fico ouvindo marchinhas para lembrar o primeiro amor

aquele big romance da adolescência

dá nela, dá nela

tento esquecer mas eles pisam pisam pisam

no céu não tem porra de lua não tem porra de nada caceta que merda

será que depois de tanta piscadela ainda posso tragar

drummond "no chão me deito à maneira dos desesperados" falar belo

assim?

tô vivendo com você num martírio sem igual

minha cabeça tá fedendo, tá saindo matéria chichilenta desse crâneo!

nunca mais tive um big romance!!

tão se beijando não vendo ó eu aqui caralho!

não é qualquer mulher que consegue conquistar meu coração

será que depois de tanta sacanagem eu ainda persisto no trilema idipiano?

(CESAR, 2013, p. 334)

Idispiando trata-se de um dos poemas mais desbocados e inacessíveis dos "Antigos e soltos". A palavra-título é um neologismo que nos reportaria à ideia de "espiar", "espiando"; o "trilema idipiano" nos sugeriria o desdobramento de um "dilema edipiano", se forçarmos na busca por um sentido - ainda assim, não parece possível fechar uma interpretação para os termos. Além disso, quando iniciamos a leitura somos apresentados a uma situação absurda: o sujeito lírico observa um casal que "dança coladinho" e de repente é por eles pisoteado, sem que os mesmos percebam o que fazem, até que de sua cabeça começa a sair uma "matéria chichilenta" e, apesar disso, ambas as partes parecem não conseguir se desvencilhar daquela situação, em um tipo de negação, o que dá o tom desajustado do poema. Enquanto é pisoteado, o sujeito lírico ainda lamenta a sua circunstância, acessa memórias, questiona o seu discurso, tudo simultaneamente, tudo no presente compartilhado com o leitor. No poema, Drummond é citado, há uma dúvida, dá para se dizer desesperado de um jeito tão belo como o poeta já fez? O próprio texto parece responder que não quando se apresenta cheio de termos "baixos" — a 

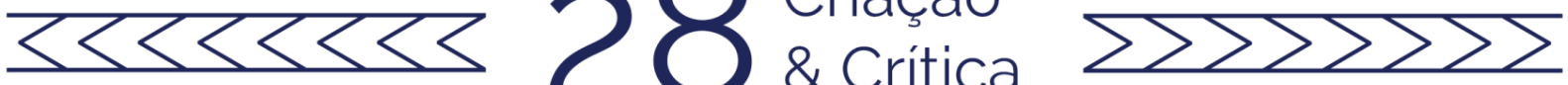

propósito, quem fala no poema fala por baixo, fala sendo pisoteado, fala sem ninguém dar a deixa, mas fala.

"Dá nela, dá nela" é uma marchinha dos anos 30 composta por Ary Barroso. O homem que canta diz para baterem na mulher que há muito tempo o provoca porque fala demais. Ana C. mistura referência de marchinha de carnaval, de samba antigo ("tô vivendo com você num martírio sem igual" trata-se de um verso da música "Pra me livrar do mal" composta por Ismael Silva e Noel Rosa) com referência de um poema consagrado da literatura brasileira. Em dois dos textos emprestados o problema da "fala" está implicado. Drummond escreve em outro momento de "Mario de Andrade desce aos infernos": "É preciso tirar da boca urgente o canto rápido, ziguezagueante, rouco, / feito da impureza do minuto/ e de vozes em febre, que golpeiam/ esta viola desatinada/ no chão, no chão." (DRUMMOND, 1987, P. 191) Ana Cristina fala através dessa "impureza do minuto", reivindicando-a. Postura que ganha força ainda maior por partir de uma escritora cujo contexto literário de sua época ainda pouco consagrava mulheres e, quando o fazia, eram mulheres que escreviam uma poesia que se encaixava nos estereótipos de uma fala inefável, branca, transcendental, que o senso comum relaciona ao feminino; com pouco corpo, com pouco chão, sem ruído. ${ }^{10}$

"Idispiando", então, parece se estruturar sobretudo através da colagem de falas, textos e referências diversas, assim como tantos outros poemas da autora, a notar pelos aqui abordados. O desconforto, o desajuste igualmente estão presentes - nesse caso, de modo intensamente explícito. A "estrutura histérica" parece se repetir aqui: seja pela forma, seja pelo conteúdo. A angústia do personagem pisoteado no poema, ao rés do chão, nos faz lembrar dos comentários de Heloisa Buarque de Hollanda em seu livro Impressões de viagem... (1980) - que já citamos - acerca da sensação de sufoco compartilhada por muitos ao longo da ditadura militar no Brasil.

Tal sensação é comentada em diversos textos que pensam a conjuntura da produção artística, literária e intelectual no Brasil sobretudo a partir do Al-5, em 1968, quando a repressão exercida pela Ditadura Militar se acirra. O sufoco marca a época das desilusões com a política, com as instituições públicas, com o engajamento - que

\footnotetext{
${ }^{10}$ Convém citar Ana Cristina falando sobre Cecília Meireles e Henriqueta Lisboa (esbarrando até em Drummond de modo que vem a calhar pelo poema em questão) no texto "Literatura e mulher, essa palavra de luxo" que já comentamos aqui:
}

As duas são figuras consagradas e que nunca inquietaram ninguém. Mas não é a consagração que critico, nem a marca nobre. Apenas acho importante pensar a marca feminina que elas deixaram, sem no entanto jamais se colocarem como mulheres. Marcaram não presença de mulher, mas a dicção que se deve ter, a nobreza e o lirismo e o pudor que devem caracterizar a escrita de mulher. É claro que há homens que também fazem poesia assim. O próprio Drummond acabou se nobilizando para não mais voltar. $\mathrm{O}$ que eu quero saber é por que as poetisas brasileiras têm optado por essa via, e não por outra. Por que mulher quando escreve se atrela a esse tipo de produção? (CESAR, 1999, p. 227) 

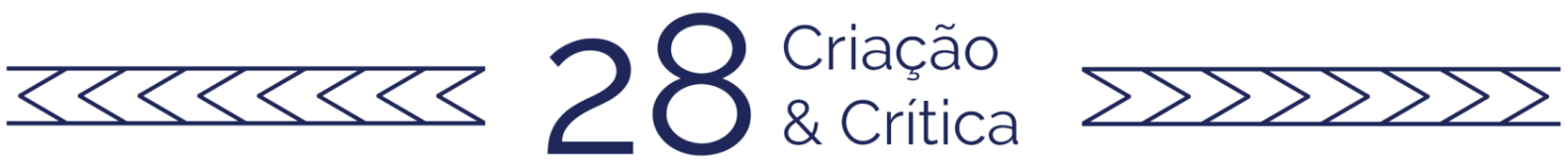

deságuam, entre outras formas, no chamado desbunde, como aponta Glauco Mattoso no seu $O$ que é poesia marginal? (1981). Hollanda, quando aborda a experiência do sufoco, distingue o modo como ela aparece em duas gerações que integrariam como um todo a "Geração Mimeógrafo" e caracteriza-a como uma "descrença em relação ao sistema e às 'linguagens sérias'” em decorrência da ditadura, da mudança drástica no desenvolvimento da vida intelectual e da esquerda no país, da repressão, do exílio. A primeira geração, representada pela coleção Frenesi, seria composta por "intelectuais que tomaram parte nos debates culturais e políticos da década de 60 e que passaram a criticar e redimensionar suas posições.", figuras como Roberto Schwarz, Antonio Carlos de Brito (Cacaso) e Francisco Alvim fazem parte dessa esfera que traria tal experiência "numa crítica que ainda passa, em muito, por uma mediação intelectual e racionalizante" (HOLLANDA, 1981, p. 114). O sufoco teria sido metabolizado de modo diferente pela segunda geração, que se encontra com a primeira na coleção Vida de Artista, tendo Chacal e Luiz Olavo Fontes como representantes, e que se sobressai na coleção Nuvem Cigana. Se, para o grupo da coleção Frenesi, a experiência do sufoco "revela-se, antes de tudo, um problema existencial" onde "o sentimento experimentado no cotidiano é também um problema teórico ${ }^{11 " ~(H O L L A N D A, ~ 1981, ~ p . ~ 115), ~ p a r a ~ o ~ g r u p o ~ d a ~ N u v e m ~ C i g a n a ~ t a l ~}$ experiência "não é mais objeto de uma reflexão ou mesmo de uma generalização. Ao contrário, o sufoco é experimentado a nível de sensações mais imediatas, promovendo antes perplexidade do que crítica conceitual."12 (HOLLANDA, 1981, p. 119).

Considerando as diferenças estabelecidas por Heloísa Buarque, diríamos que na obra de Ana Cristina encontraríamos ambos os modos de trabalhar com essa tal experiência do sufoco. Idispiando nos apresenta explicitamente um desespero que provém sobretudo do lugar e do modo como o corpo se insere no poema, o que faz ressoar o comentário de Heloísa sobre a Nuvem Cigana - contudo, em meio ao rebuliço, ainda se encontra espaço para pensar o lugar da literatura quando Drummond é citado (ou seja, passa-se por e exige-se também um processo reflexivo). O questionamento levantado no texto, que proclama certa impossibilidade de construção do convencionado "belo" frente ao desespero, o conecta a algumas intervenções realizadas em relação à

11 Como no poema de Schwarz que Hollanda aborda:

\section{Ulisses}

A esperança posta num belo salário corações veteranos

Este vale de lágrimas. Estes píncaros de merda. (HOLLANDA, 1980, p.

${ }^{12}$ Como no poema de Charles que Hollanda também aborda:

colapso concreto

vivo agora uma agonia:

quando ando nas calçadas de Copacabana

penso que sempre vai cair um troço na minha cabeça (HOLLANDA, 1980, p. 120) 

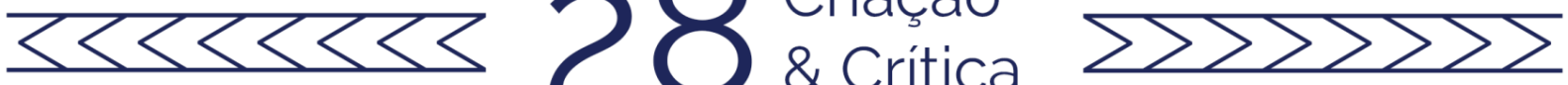

obra do poeta consagrado por artistas próximos ao contexto de Ana C., como o trabalho de Silvio Spada, que "publicou um punhado de cinzas num saquinho de fubá com uma frase impressa: 'Sílvio Spada queimou um poema de Carlos Drummond de Andrade'." (MATTOSO, 1981, p. 36) e como o ato de representantes da chamada "vanguarda processo" que, diz Heloísa, "num protesto contra a discursividade e a retórica literária, em grande espetáculo público, chegaram a picar Drummond em pedaços - não o poeta, mas seus livros - , nas escadarias do Teatro Municipal num belo dia de verão carioca." (HOLLANDA, p. 57).

Identificamos na produção de Ana Cristina Cesar um desejo de investigar questões desafiadoras para a escrita tanto a nível conceitual quanto a nível de experiência e circunstância. Esse fator, por sua vez, muito diminui ou mesmo extingue o abismo entre um certo imediatismo de criação e apreensão versus um longo rigor intelectual. Idispiando se escreve, assim, como uma reivindicação do "feio", do "mal gosto" como via de escrita plausível perto de um "belo" que, a certa altura, parece sério demais, cômodo demais para tocar o leitor - ou seja, ao mesmo tempo em que comporta um vocabulário "baixo", demanda e suscita ponderação. A proposta, então, segue a mesma linha de poemas que já pensamos aqui, como "25 de maio de 1976".

Por outro lado, lidamos com o embate que a não-publicação de tais textos pela própria autora desperta. Poderíamos, afinal, lê-los dentro de um certo projeto presente na obra de Ana $C$. se tanto se distinguem do material de $A$ teus pés, por exemplo, se situando "à sombra" de suas escolhas? Qual é a relevância de nos voltarmos a eles neste momento? Bem, é clara a distinção entre o caráter explícito dos textos aqui trabalhados e as elipses que perpassam grande parte dos poemas presentes na recolha de 1982. A maioria do público se aproxima de sua obra sobretudo através dessas elipses, desses poemas que não dão nada de mão beijada, e que muitas vezes por esse motivo capturam e estimulam o leitor. O nosso interesse pela sombra se justifica quando, apesar de todas as diferenças, identificamos nos poemas da Pasta Rosa semelhanças quanto à temática $\mathrm{e}$ aos procedimentos constitutivos (como a alegoria, a colagem, o registro do diário) dos poemas legitimados pela autora: se de um lado certas questões aparecem como latência, do outro elas estão escancaradas. Vemos, portanto, uma relação complementar entre uma faceta e outra. Depois que lemos os poemas da Pasta Rosa, voltamos com outros olhos para $A$ teus pés - o que foi deixado à sombra, ironicamente, nos ajuda a esclarecer ou mais expressamente identificar intenções e procedimentos.

111

Considerando o teor dos poemas até então abordados, o aspecto "político-literário" se revela um ponto importante dentro das inquietações de Ana Cristina Cesar. Com o intuito de ressaltar o compromisso político assumido por Ana $C$. enquanto escritora e intelectual, recuperamos, via Ítalo Moriconi em seu livro Ana Cristina Cesar: o sangue de uma poeta (1996), o conteúdo da lista de princípios básicos elaborada por ela para as 

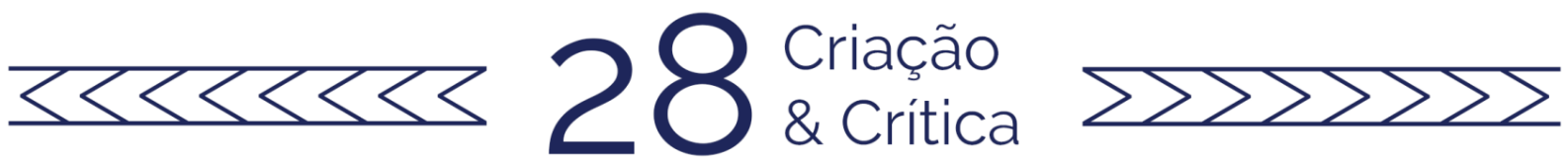

primeiras reuniões do jornal que veio a se chamar "Beijo", tendo sete números publicados entre novembro de 1977 e junho de 1978 (projeto dissidente do jornal Opinião, ambos inseridos no contexto de mídia alternativa durante a ditadura militar), quando seus fundadores discutiam o enfoque, a temática e o papel do veículo de comunicação que intuíam lançar:

1. Dessacralização: descompromisso com nomes ou figuras sagradas ou "aliadas"; descompromisso com os temas em cartaz.

2. Função de desrecalque: fazer falar temas e tons que são recalcados (principalmente pela esquerda encastelada).

3. Descentralização: muito espaço para o leitor, que pode se tornar colaborador. Desconcentração na estrutura de poder. Mobilidade.

4. Emergência de contradições: desmontagem da frente ampla. A seleção de matérias só tem sentido em função de uma estratégia e não de um recalque, de uma intervenção autoritária. Descentralização opinativa.

5. Linguagem: produção alternativa à linguagem da imprensa e à linguagem universitária. Discussão dos "conteúdos subjacentes" às matérias. Explicitação do autoritarismo das articulações discursivas.

"O modo como são articulados termos e proposições e linguagem, longe de ser uma simples forma, tem uma intrínseca relação com a chamada mensagem. Aos homens de exclusiva boa vontade deve-se fazer ver que inclusive podem ser surpreendidos por isto que, na ausência de um termo melhor, podemos chamar de conteúdo subjacente"

Rodrigo F. Naves, no Opinião

Nós podemos ser surpreendidos.

6. Competência: questionamento do conceito. A seleção de matérias se faz a partir de uma estratégia e não de um conceito pré-fixado de "competência". Contra a seguinte colocação:

"Na minha opinião quem está em 'posição privilegiada' é o Sr. Leib que ainda cheirando a leite pensa ter competência para julgar e agredir baseado em meias-verdades. Porém ninguém melhor para combater as críticas irresponsáveis do que aqueles profissionais a quem esse jornal deve recorrer"

Eduardo Ebenezer Ofeliano de Almeida, leitor de Opinião (eu grifei)

7. Estratégia: possibilidade de constante questionamento da estratégia, que está sempre a um passo do autoritarismo. A estratégia se manifesta muito menos pelo veto do que pela montagem e articulação das matérias. Ex.: carta de leitor que não interessa pode figurar como carta mesmo. $O$ discurso apologético de um Fernando Peixoto por exemplo pode ser denunciado no confronto estratégico com outra matéria.

8. prática política e vida cotidiana: questionamento da distância ENTRE as propostas que norteiam a prática política e as relações cotidianas. * Que inclusive se manifesta no próprio discurso (ver oposição entre "conteúdo progressista" e articulação autoritária - a certeza do próprio saber, a fala só 

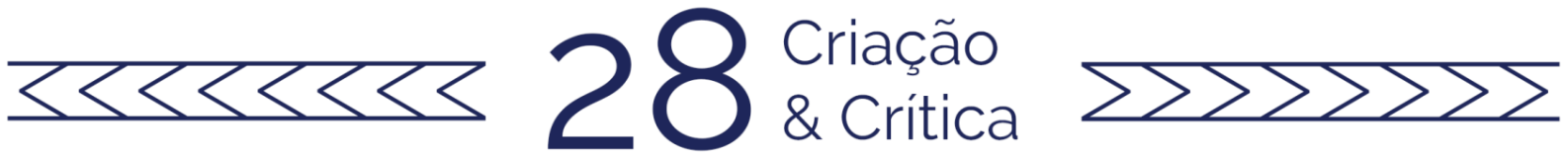

para iniciados). Cito outra vez Rodrigo Naves e proponho republicação do seu "Contra a existência distraída".

* Ou: entre afeto e estratégia

Ou: entre "subjetivo" e "objetivo"

(MORICONI, 1996, pp. 47-49)

Uma vez que tais princípios se configuram como referências para se estabelecer relação com o outro, com o leitor - e, como já sabemos, essa é uma inquietação constante na poesia de Ana Cristina - podemos analisá-los em relação à obra da autora como um todo. A dessacralização aqui entra como uma reivindicação de liberdade quando aborda o "descompromisso com os temas em cartaz", assim como acontece quando, na poesia, a autora preocupa-se em preservar investigações e inquietações próprias para além de tendências da sua geração, questão abordada em "a lei do grupo" presente na Pasta Rosa ${ }^{13}$. A função de desrecalque nos transporta diretamente para a questão do corpo: ainda que aqui apareça de modo mais genérico, está posto o desejo de trazer à tona aquilo que se almeja abafar em todos os âmbitos da linguagem. É interessante notar, também, a presença do termo tão utilizado por Flora Süssekind ao pensar a questão do sujeito em sua poesia: a descentralização. Ele aparece, nesta ocasião, para reivindicar a mobilidade das falas como antídoto às posições rígidas de poder, uma qualidade que vai ao encontro da ideia de "descentralização do sujeito" trabalhada por Süssekind, uma vez que a proposta é justamente dar conta de certa pluralidade de vozes. A emergência de contradições, por sua vez, se relaciona com as constantes tensões presentes nos poemas de Ana Cristina, onde tantas vezes nos deparamos com a dificuldade de formar ou captar uma imagem ou mensagem fixa, completamente amarrada: conseguimos ver, então, o propósito de abertura ao leitor. Todos os outros termos pontuados vão evidenciar importantes preocupações éticas quanto à produção de conteúdo em um jornal em meio à ditadura e aos conflitos existentes dentro da própria esquerda, que enfrenta diversos desafios para existir, defender um posicionamento e propagar as suas ideias.

Ainda que o Jornal Beijo não se situasse estritamente no âmbito da literatura, estando mais ligado ao terreno do jornalismo cultural, vemos como para Ana C. esse fato não desmobilizava questões que atravessavam o campo da escrita literária. Por outro lado, poetas como Glauco Mattoso realizavam, na mesma época, publicações, jornais igualmente independentes que viriam a tematizar diretamente a história recente da nossa literatura de modo crítico e propositivo. Mattoso revê o Manifesto Antropofágico e o modernismo brasileiro como um todo sob o viés "destrutivo" de correntes como o dadaísmo, negadas pelos modernistas que reservavam às suas propostas uma via de construção de identidade nacional. Sendo assim, o poeta lança o seu Manifesto

\footnotetext{
13 " a lei do grupo

'todos os meus amigos estão fazendo poemas-bobagens ou poemas-minuto'"
} 

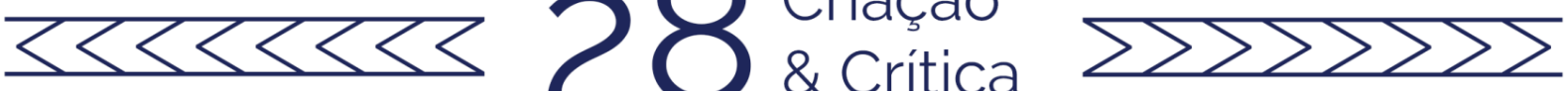

Cropofágico ${ }^{14}$, que serviria como "princípio construtivo" do Jornal Dobrabil, publicação por ele editada de 1977 a 1980. Mario Cámara, em livro já citado, comenta, entre outras coisas, que:

$\mathrm{Na}$ dadaização satírica da antropofagia, a fecalidade sofre um deslocamento e adquire um estatuto central ao funcionar como matéria heterológica. Sua presença na manifestação de um trabalho consiste em fazer visíveis os princípios impuros de qualquer discurso que se apresente como homogêneo e fechado. (CÁMARA, 2015, p. 35)

Levando em conta o documento acima citado e os poemas que aqui analisamos, Ana Cristina parece alinhada com Mattoso no gesto de identificar a reivindicação do teor destrutivo e de certa "fecalidade" como uma contraposição a discursos homogêneos e fechados. Com isso, lembramos também da citação de Cámara feita nas páginas anteriores, onde o corpo e suas adjacências é identificado como resposta a perguntas sobre como nos anos 70 a poesia responderia aos seus movimentos predecessores, principalmente às vanguardas do início do século. Se a mastigação e a ingestão constituem um processo de homogeneização, a defecação trata-se de um gesto de heterogeneização, onde a matéria ingerida vai mudar de forma e voltar ao mundo. Como Ana Cristina vem a se aproximar dessa prática? Como essa questão dos usos do corpo na escrita nos aponta para a inquietação de Ana C. em conferir corporeidade ao poema (desencadeada por uma espécie de conflito que estabelece com os limites da linguagem $)^{15}$ ?

A escritora, então, se deparara com os tais limites impostos pela linguagem (que, ao mesmo tempo que nos aproxima do outro, o faz de uma maneira delimitada: nunca seremos nós mesmos alcançando o outro, apenas as palavras; o que não

14 "O princípio construtivo que organizava o conjunto textual heterogêneo do Jornal, era a cropofagia, palavra composta a partir de dois termos gregos, copros (fezes) e phagein (comer), que descreve o gosto pela ingestão de material fecal. Mattoso levantava como fundamento central do seu projeto que, se a antropofagia oswaldiana propusera-se como uma devoração ativa da cultura estrangeira, a sua cropofagia se apresentava como a devoração dos detritus despejados pela antropofagia" (CÁMARA, 2015, p. 21)

${ }_{15}$ Questões semelhantes são levantadas nos trabalhos realizados por Annita Costa Malufe sobre a escrita de Ana Cristina Cesar. Seguindo a discussão colocada no capítulo "Um universo próprio, o corpo do poema", de Territórios dispersos: a poética de Ana Cristina Cesar (2006), Annita desenvolve as suas ideias no capítulo "Interlocução, a presença do corpo" do livro Poéticas da Imanência: Ana Cristina Cesar e Marcos Siscar (2011). Nele, a pesquisadora conclui que a corporeidade do poema tão almejada pela escrita de Ana Cristina Cesar se alcança quando o que salta nos textos são as interpelações ao leitor, aquelas "expressões ou interpolações vazias de significado, como os exemplos que podemos tirar do dia-a-dia: 'você está me ouvindo?', 'escuta aqui', 'sabe, 'não é mesmo?'” (MALUFE, 2011, p. 184). Tais expressões, que exercem o que conhecemos como a função fática da linguagem, seriam tão predominantes em tantos poemas de Ana C., que poderíamos encará-los como se "fossem textos inteiramente 'fáticos", diz Annita. Tal característica evidenciaria que tudo o mais que viesse a constituir o poema estaria em segundo plano, sendo a interlocução, o apelo ao outro, o aspecto mais importante da sua existência, "resultando em uma linguagem em que a função comunicativa e informativa perde a sua força" (MALUFE, 2011, p. 186). Esvaziado, então, de algum conteúdo passível de ser comunicado, o poema estaria pronto para existir por si mesmo, em uma auto-enunciação, tornando-se uma entidade e ganhando um corpo para, assim, atingir o outro corpo, o do leitor. 

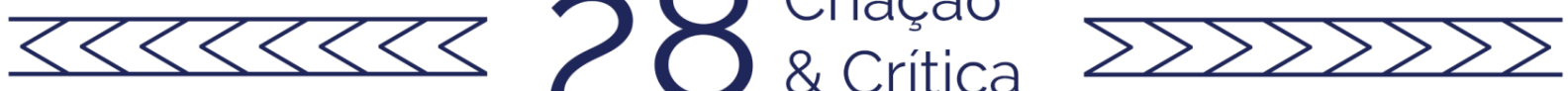

necessariamente é pouco, mas é um limite) e se debate contra eles, em uma inquietação que se deflagra tanto pelos aspectos formais quanto temáticos de muitos dos seus poemas - por isso falar do corpo, da sua intimidade e excrescência, falar em primeira pessoa, falar em diário, fazer uso dos vocativos e das "expressões fáticas" etc : todos esses podem ser recursos que giram em torno da interpelação do outro e da confrontação de limites, da criação de uma força assertiva do texto. O ponto não se trataria, portanto, do alcance de um vazio de sentido, mas de como se preenche o texto e se constrói esse sentido. Os poemas teriam um estofo tão grande que transbordariam e chegariam, assim, ao outro ${ }^{16}$.

Um texto que é corpo e que se compõe a partir de trocas múltiplas com outros corpos. Poderíamos pensar, assim, que o modo como a obra Ana Cristina Cesar se aproximaria de certa fecalidade acima mencionada se dá através de uma escrita residual, recuperando a raiz da palavra fezes (de faeces em grego, resíduos). De tudo fica um pouco. Nesse jogo de reescritura e reelaboração do que veio antes, a poeta constrói a sua escrita, exercita a sua voz sem jamais falar sozinha, necessitando da interlocução para viabilizar a sua existência. Malufe, por sua vez, em ensaio recente intitulado Ana Cristina Cesar: o poema-corpo ou o poema voltado para fora de si (2018) ${ }^{17}$ faz uma distinção pontual entre dois tipos fundamentais de interlocução que estariam presentes na escrita de Ana C.: a interlocução interna ou implícita, em que "o poema é feito de fragmentos de outros autores, que no arranjo final acabam dialogando entre si e/ou com a voz do próprio poema" e a interlocução externa ou explícita, em que "o poema se dirige a um interlocutor externo, um você, leitor, que figura como personagem no poema, nomeado ou não. Em um e noutro caso, a interlocução indica um gesto generalizado em sua escrita: gesto de diálogo, conversa, remissão a diversos outros." (MALUFE, 2018, p. 432) Tal interlocução múltipla, portanto, é também um importante fator que oferece o lastro e conduz o aspecto residual-corpóreo fundamental na escrita de Ana Cristina Cesar.

Por fim, a partir dos poemas então abordados, dimensionamos não só uma certa radicalidade com a qual a autora flertava, mas também o caráter de suas escolhas, o seu processo de triagem, edição e elaboração. Supomos que a opção de Ana C. por deixar "à sombra" os poemas de cunho mais explícito, cujas intenções são escancaradas, pode estar relacionada sobretudo a uma recusa em induzir leituras fáceis, imediatas, superficiais - e não a um tipo de pudor pelo conteúdo "escatológico" de certos textos,

${ }^{16} \mathrm{E}$, nesse ponto, nos identificamos com o modo como Malufe imagina essa transposição:

(...) talvez então, estejamos diante de um texto que é corpo, ainda que não um corpo de carne e osso. Poderíamos, assim, alargar a nossa concepção de corpo, e imaginar uma linguagem que é ela mesma corpo, é um corpo que afeta outros corpos; linguagem tátil, sonora, plástica, algo do que declara Barthes em seus Fragmentos de um discurso amoroso acerca da linguagem de que se servem os amantes: "A linguagem é uma pele: esfrego minha linguagem no outro. É como se eu tivesse palavras ao invés de dedos, ou dedos na ponta das palavras" (MALUFE, 2011, p. 187)

17 Publicado no livro de ensaios organizado por Viviana Bosi e Renan Nuernberger intitulado Neste instante: novos olhares sobre a poesia brasileira dos anos 1970 (2018). 

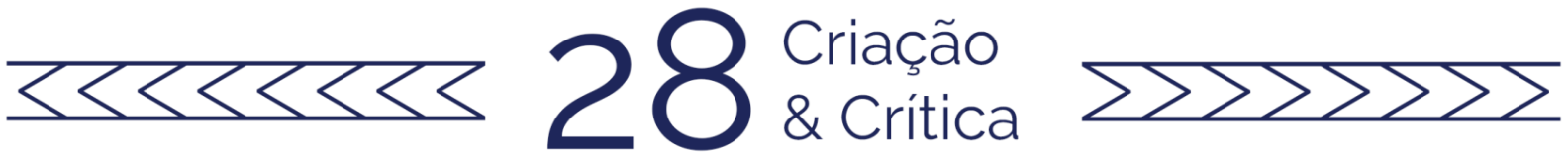

conteúdo esse que se expressa, justamente, como potência. Acreditamos que a autora hesitasse diante do perigo de cair em simplismos, desconfiando de uma certa literalidade inerente a esses elementos escatológicos e se perguntando até que ponto provocariam e até que ponto anestesiariam - ao mesmo tempo em que estava ali, jogando e experimentando com eles. Para nós, sua importância advém de uma verve contestatória e transgressora que abriu vias para importantes investigações na produção da poesia contemporânea brasileira, sobretudo para as mulheres escritoras. Verve que se revela, de uma vez por todas, nos poemas aqui analisados.

\section{Referências}

ANDRADE, Carlos Drummond. A rosa do povo. Rio de Janeiro: Record, 1987

BENJAMIN, Walter. A Origem do Drama Barroco Alemão. São Paulo: Brasiliense, 1984.

BOSI, Viviana (Org.); NUERNBERGER, Renan. (org.). Neste Instante: novos olhares sobre a poesia brasileira dos anos 70. São Paulo: Humanitas: FAPESP, 2018

CÁMARA, Mario. Corpos Pagãos: usos e figurações na cultura brasileira (1960-1980). Tradução de Luciana di Leone. Belo Horizonte: Editora UFMG, 2014.

CESAR, Ana Cristina. Poética. São Paulo: Companhia das Letras, 2013

Crítica e Tradução. São Paulo: Editora Ática, 1999.

HOLLANDA, Heloisa Buarque de. Impressões de viagem (cpc, vanguarda e desbunde: 1960/70). Rio de Janeiro: Aeroplano, 2004.

MALUFE, Annita Costa. Poéticas da imanência: Ana Cristina Cesar e Marcos Siscar. Rio de Janeiro e São Paulo: 7Letras e FAPESP, 2011.

MARCHI, Tatiane; FRANCHETTI, Paulo. Ana Cristina Cesar e a poesia marginal. Revista Língua, Literatura e Ensino, v. IV. Maio/2009. P

p. 385-94.

MATTOSO, Glauco. O que é poesia marginal. São Paulo: Brasiliense, 1982.

MORICONI, Ítalo. Ana Cristina Cesar: o sangue de uma poeta. Rio de Janeiro: Relume Dumará, 1996.

SCHWARZ, Roberto. O pai de família e outros estudos. Rio de Janeiro: Paz e Terra, 1978

SISCAR, Marcos. De volta ao fim: o "fim das vanguardas" como questão da poesia contemporânea. Rio de Janeiro: 7Letras, 2016.

SÜSSEKIND, Flora. Até Segunda Ordem não me risque nada. Rio de Janeiro: 7Letras, 1995

Recebido em: 07/04/2020

Aceito em: 30/09/2020

Referência eletrônica: MORSE, Fernanda. "Dá pra falar belo assim?": Ana Cristina Cesar, embates e figurações do corpo na escrita. Criação \& Crítica, n. 28, p., dez. 2020. Disponível em: <http://revistas.usp.br/criacaoecritica>. Acesso em: dd mmm. aaaa 